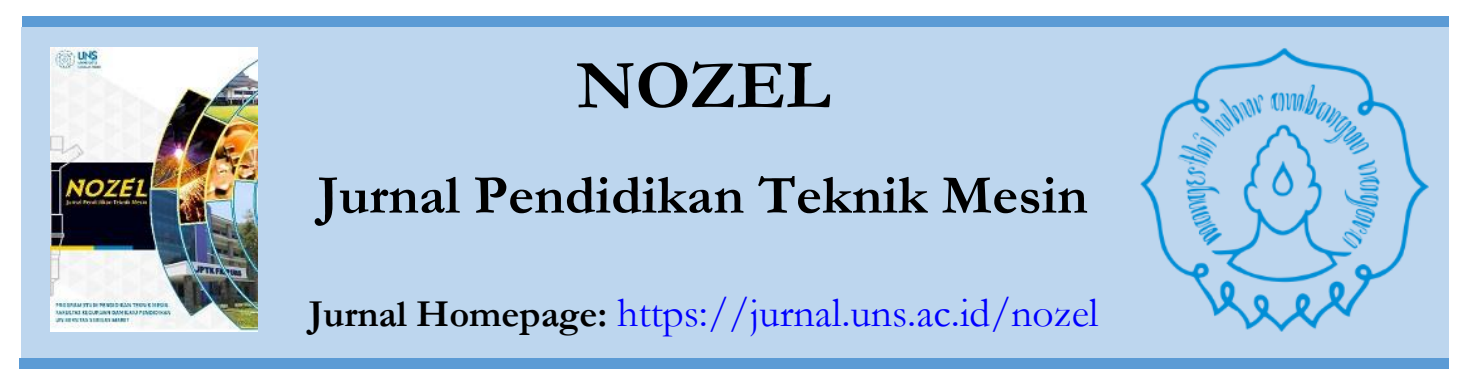

\title{
UPAYA MENINGKATKAN MOTIVASI DAN HASIL BELAJAR SISWA MELALUI MODEL PEMBELAJARAN PRACTICE REHEARSAL PAIRS PADA PEMBELAJARAN PRAKTIK PEMESINAN KELAS XI TMB SMK BHINNEKA KARYA SURAKARTA
}

\author{
Arseta Budi Utomo ${ }^{1}$, Danar Susilo Wijayanto ${ }^{1}$ Basori $^{1}$ \\ ${ }^{1}$ Program Studi Pendidikan Teknik Mesin, FKIP, Universitas Sebelas Maret Surakarta \\ e-mail: arseta.budiutomo@gmail.com
}

\begin{abstract}
The research is intended to improve successfully learning motivation and achievement in Mechanical Engineering $B, 11^{\text {th }}$ grade at vocational high school of Bhinneka Karya Surakarta in Machinery Practical Learning using Practice Rehearsal Pairs learning model. The research is Classroom Action Research that conducted in two cycles. Each cycle consisted of four stages, there are: planning, acting, observing, and reflecting. The instruments to collect the data, there are questionnaire, interview, test, observation, and documentation. The data was carried out using descriptive qualitative analysis. The result of research showed that there is an improvement in students' learning motivation and achievement. The student' learning motivation increased from $74.5 \%$ in cycle 1 to $92.59 \%$ of students having learned motivation belonging to minimally good category in cycle 2. The students' cognitive learning achievement increased from $66.67 \%$ to $88.89 \%$, the affective learning achievement increased from $81.48 \%$ to $85.19 \%$, and the psychomotor learning achievement of students increased from $74.07 \%$ to $88.89 \%$ of students who could achieve $M P C$.

Keywords: Learning Motivation, Achievement, Practice Rehearsal Pairs learning model, Classroom Action Research
\end{abstract}

\section{A. PENDAHULUAN}

Sekolah Menengah Kejuruan (SMK) merupakan suatu bentuk satuan pendidikan yang mengutamakan pengembangan kemampuan siswa untuk melaksanakan jenis pekerjaan tertentu. Siswa SMK dibekali dengan suatu keahlian, sehingga mereka memiliki kualitas individu yang mampu bersaing di industri maupun wirausaha. Inilah yang menjadi tujuan seluruh SMK di Indonesia, termasuk SMK Bhinneka Karya Surakarta.

SMK Bhinneka Karya Surakarta mempersiapkan siswanya untuk memiliki kompetensi, profesionalisme, dan karakter unggul dalam bersaing di dunia kerja nasional. Untuk mencapai cita-cita tersebut, lembaga ini senantiasa 
menyelenggarakan kegiatan belajar dapat dikatakan rendah. Hal ini berimbas mengajar secara efektif dan profesional. pada hasil belajar siswa. Nilai-nilai siswa, Pembelajaran praktik yang dilakukan pun baik dalam pengetahuan, keterampilan, dirasa telah berjalan dengan cukup baik, maupun sikap pada semester sebelumnya namun kurang maksimal. Hal ini terbilang rendah dengan banyaknya siswa ditunjukkan dengan motivasi belajar siswa yang belum mencapai Kriteria Ketuntasan yang terhitung rendah disertai dengan hasil belajar yang rendah pula.

Aunurrahman (2014: 114) berpendapat bahwa motivasi merupakan pendorong seseorang dalam melakukan sesuatu dengan penuh semangat. Motivasi akan menggugah siswa untuk mau belajar, sehingga tujuan belajar tercapai, seperti yang diungkapkan Purwanto (2014: 73). Motivasi siswa yang rendah pada kelas XI TMB SMK Bhinneka Karya Surakarta terlihat pada banyaknya siswa yang kurang antusias mengikuti praktik. Hasil observasi menunjukkan bahwa beberapa siswa hanya berbincang-bincang, sementara siswa lainnya melakukan pekerjaan. Purwanto (2014: 60) berpendapat bahwa motivasi merupakan syarat mutlak untuk belajar, baik internal maupun eksternal. Tanpa adanya motivasi, siswa tidak akan memiliki semangat dalam mengikuti proses belajar.

Motivasi ini mampu menumbuhkan perhatian siswa terhadap materi ajar. Apabila motivasi siswa rendah, maka perhatian mereka terhadap materi ajar pun

\section{Minimal (KKM).}

Nilai-nilai tersebut merupakan ukuran hasil belajar siswa sebagai output dari proses belajar. Proses belajar berlangsung dengan mengolah raw input yaitu siswa dengan memberikan perlakuan berupa proses belajar mengajar (teaching-learning process). Bloom (Suprijono, 2015: 6) membagi hasil belajar dalam tiga macam garis besar yaitu: a) kemampuan kognitif; b) kemampuan afektif; c) kemampuan psikomotorik.

Selama proses belajar mengajar berlangsung terdapat faktor-faktor yang memengaruhi hasil belajar tersebut. Menurut Purwanto (2014: 106), faktor yang memengaruhi ini bisa berasal dari lingkungan yang menjadi masukan lingkungan (environmental input) maupun faktor yang sengaja dirancang (instrumental input). Permasalahanpermasalahan pada pembelajaran praktik ini disebabkan oleh beberapa faktor. Faktor yang pertama yaitu jumlah mesin yang tidak sebanding dengan jumlah siswa. Kondisi seperti ini mengharuskan 
siswa bergantian dalam menggunakan mesin, sehingga memunculkan waktu tunggu atau mengantre. Waktu menunggu giliran tersebut menyebabkan siswa tidak produktif, mereka hanya duduk dan berbincang-bincang.

Faktor kedua adalah banyaknya siswa yang masih membutuhkan panduan langsung, sedangkan jumlah guru pengampu hanya dua orang setiap kelasnya. Hal ini membuat guru pengampu tidak dapat merangkul seluruh siswa saat melakukan praktik.

Faktor yang ketiga yaitu metode yang diterapkan dalam pembelajaran hanya bersifat konvensional dan kurang tepat diterapkan pada keterbatasan kondisi tersebut.

Meninjau pada kemungkinan penyebab di atas, inovasi pembelajaran perlu dilakukan. Salah satu model pembelajaran yang dapat diterapkan adalah model pembelajaran Practice Rehearsal Pairs (Praktik Berpasangan). Silberman (2009: 228) mengatakan bahwa model tersebut merupakan strategi sederhana untuk melatih kecakapan atau prosedur dengan partner belajar. Practice Rehearsal Pairs adalah model pembelajaran yang mampu meningkatkan aktivitas siswa di dalam pembelajaran praktik pemesinan, sehingga siswa tidak hanya terdiam menunggu giliran menggunakan mesin.

Langkah-langkah pelaksanaan model pembelajaran Practice Rehearsal Pairs telah dijelaskan oleh Suprijono (2015: 135) sebagai berikut: a) Memilih sebuah kecakapan yang ingin dikuasai siswa kemudian membuat kelompok kecil, setiap kelompok terdiri dari 2 orang; b) Dalam kelompok tersebut, satu orang sebagai demonstrator dan satu lagi sebagai penginspeksi; c) Kedua siswa kemudian bertukar peran; d) Kecakapan tersebut dilakukan terus menerus hingga semua kecakapan dikuasai.

Interaksi antar siswa akan memberikan rasa nyaman yang akan meningkatkan motivasi belajar. Aunurrahman (2014: 114) berpendapat bahwa motivasi belajar yang kuat dapat meningkatkan hasil belajar. Interaksi juga akan menimbulkan pertukaran pendapat melalui diskusi yang mampu meningkatkan pemahaman siswa. Dengan demikian akan terjadi peningkatan terhadap kualitas pembelajaran siswa termasuk motivasi dan hasil belajar siswa.

\section{B. METODE}

Penelitian ini merupakan Penelitian Tindakan Kelas (PTK) atau dalam bahasa Inggris disebut Classroom Action Research yang dilaksanakan di SMK 
Bhinneka Karya Surakarta yang beralamat di Jalan Letjen. Suprapto 34 Surakarta. Penelitian dilakukan terhadap siswa kelas XI TMB yang berjumlah 27 orang dalam pembelajaran praktik di laboratorium mesin bubut dan mesin frais SMK Bhinneka Karya Surakarta. Rangkaian penelitian ini berlangsung mulai bulan Januari hingga Juni 2016 yang terdiri dari persiapan penelitian, pelaksanaan tindakan, serta analisis data dan pelaporan.

Teknik pengumpulan data yang digunakan dalam penelitian ini yaitu angket, wawancara, dan dokumentasi untuk data motivasi belajar, serta teknik tes, observasi, dan dokumentasi untuk data hasil belajar siswa. Teknik-teknik tersebut digunakan untuk kepentingan triangulasi teknik sebagai teknik uji validitas data.

Analisis data pada penelitian ini dilakukan secara deskriptif kualitatif. Hal ini sesuai dengan pernyataan Sukmadinata (2006: 156), yang mengatakan bahwa analisis dalam penelitian tindakan dengan pendekatan kualitatif bersifat naratifkualitatif dalam bentuk deskripsi. Analisis dalam penelitian ini dilakukan melalui lima tahap yaitu: pengumpulan data, reduksi data, pemaparan data, interpretasi data, dan pembandingan hasil analisis data tiap siklus.
Indikator keberhasilan penelitian ini yaitu sebesar $85 \%$ siswa mampu memperoleh motivasi belajar berkategori baik dan $85 \%$ siswa mampu mencapai KKM untuk masing-masing hasil belajar. KKM untuk pembelajaran Praktik Pemesinan kelas XI SMK Bhinneka Karya Surakarta adalah 78 .

Penelitian tindakan kelas ini dilakukan dalam dua siklus di mana tiap siklusnya terdiri atas empat tahap yaitu: perencanaan, pelaksanaan, pengamatan, dan refleksi. Tahap perencanaan meliputi: perencanaan pembelajaran, penyiapan job sheet, dan pembuatan instrumen. Tahap pelaksanaan tindakan tiap siklusnya dilakukan dalam dua kali pertemuan. Tahap pengamatan dilakukan bersamaan dengan tahap pelaksanaan yaitu untuk mengamati siswa saat pelaksanaan tindakan tersebut. Tahap refleksi dilakukan untuk mengevaluasi pelaksanaan tindakan.

Siklus 1 dilakukan secara sederhana dengan menerapkan model pembelajaran Practice Rehearsal Pairs sesuai prosedur yang dijelaskan oleh Suprijono (2015: 135). Siklus 2 dilakukan secara lebih kompleks dengan menambahkan penggunaan Work Preparation Sheet dan Tabel Parameter Pemotongan dalam penerapan model pembelajaran Practice Rehearsal Pairs. 


\section{HASIL DAN PEMBAHASAN}

Penelitian ini dilakukan dalam 2 siklus tindakan yang sebelumnya telah didahului dengan pratindakan.

\section{Pratindakan}

Pembelajaran praktik pemesinan sebelum model pembelajaran Practice Rehearsal Pairs diterapkan berjalan dengan kurang kondusif. Hal tersebut ditunjukkan dengan banyaknya siswa yang terlihat tidak fokus mengikuti pembelajaran dan lebih sering berbincangbincang dengan sesama teman yang menunggu giliran. Beberapa siswa yang tidak terawasi oleh guru bahkan dengan mudah meninggalkan laboratorium ketika pembelajaran berlangsung. Hal tersebut disebabkan oleh kebosanan siswa dalam menunggu giliran menggunakan mesin.

Teori dalam pembelajaran dilakukan terhadap siswa yang duduk bersaf sebelum mengerjakan job. Pembelajaran seperti ini membuat hasil belajar tidak maksimal karena siswa tidak fokus mendengarkan penjelasan dari guru. Pengamatan sebelum tindakan menunjukkan bahwa masih banyaknya siswa yang memerlukan bimbingan dari guru bahkan harus dicontohkan terlebih dahulu. Beberapa siswa bahkan masih canggung dalam mengoperasikan mesin bubut. Hal tersebut disebabkan oleh rendahnya pengalaman siswa dalam melakukan pekerjaan praktik.

Rendahnya pengalaman ini juga menyebabkan rendahnya kepercayaan diri siswa dalam melakukan pekerjaan. Kepercayaan diri siswa inilah yang menjadi salah satu penyebab rendahnya hasil belajar siswa, seperti yang telah diterangkan Aunurrahman (2014: 184) bahwa rasa percaya diri memengaruhi hasil belajar.

Pengambilan data mengenai motivasi belajar pada pratindakan dilakukan melalui pengamatan dan menyebutkan bahwa $\pm 50 \%$ siswa terlihat pasif dalam mengikuti pembelajaran praktik. Pengambilan data mengenai hasil belajar pratindakan dilakukan melalui studi dokumentasi. Rincian data hasil belajar pratindakan dapat dilihat pada Tabel 1 berikut:

Tabel 1. Data Hasil Belajar Siswa Pratindakan

\begin{tabular}{cc}
\hline Hasil Belajar & $\begin{array}{c}\text { Persentase } \\
\text { Ketuntasan KKM }\end{array}$ \\
\hline Pengetahuan & $66,67 \%$ \\
Keterampilan & $70,37 \%$ \\
Sikap & $62,96 \%$ \\
\hline
\end{tabular}

Siswa yang mampu melampaui KKM untuk hasil belajar kognitif (pengetahuan) sebanyak 18 siswa atau sebesar 66,67\%. Sebanyak 19 siswa $(70,37 \%)$ telah mampu melampaui KKM 
untuk hasil belajar psikomotorik (keterampilan) dan 17 siswa (62,96\%) untuk siswa yang mampu melampaui KKM hasil belajar afektif.

\section{Siklus 1}

Siswa pada pembelajaran Siklus 1 terlihat meningkat keikutsertaannya dibandingkan pada pembelajaran pratindakan. Siswa terlihat lebih aktif dengan berusaha mencari tahu langkah yang benar dalam mengerjakan job dengan bertanya kepada guru. Hal ini menunjukkan bahwa ada peningkatan motivasi belajar siswa setelah diberikan tindakan berupa model pembelajaran Practice Rehearsal Pairs. Data motivasi belajar dapat dilihat pada Tabel 2 berikut: Tabel 2. Data Motivasi Belajar Siswa Siklus 1

\begin{tabular}{cc}
\hline Kategori & Persentase \\
\hline Sangat Baik & $40,7 \%$ \\
Baik & $33,3 \%$ \\
Cukup & $26 \%$ \\
Kurang & 0 \\
Sangat Kurang & 0 \\
\hline
\end{tabular}

Data di atas menyebutkan sebesar 40,7\% siswa memiliki motivasi belajar berkategori sangat baik dan 33,3\% siswa berkategori baik. Ini berarti sebesar $74 \%$ siswa telah mencapai motivasi belajar berkategori baik.

Penerapan model pembelajaran ini bahkan mampu menghilangkan adanya siswa yang tidak produktif karena menunggu giliran. Meskipun demikian, masih terdapat beberapa siswa yang terlambat datang ke laboratorium, sering bercanda dengan kelompok mesin lain, bahkan mengganggu teman yang sedang mengerjakan job.

Sikap siswa yang berubah lebih serius menyebabkan materi yang disampaikan dapat diserap dengan lebih baik. Namun demikian, tidak serta merta meningkatkan pemahaman siswa terhadap teori. Hal ini disebabkan kondisi pembelajaran yang masih belum kondusif. Siswa masih banyak yang tidak percaya diri dan takut melakukan kesalahan saat mengerjakan job. Hal ini berpengaruh pada hasil dan waktu serta langkah mereka dalam bekerja. Hasil belajar pada siklus 1 dapat dilihat pada Tabel 3 berikut:

Tabel 3. Data Hasil Belajar Siswa Siklus 1

\begin{tabular}{cc}
\hline Hasil Belajar & $\begin{array}{c}\text { Persentase } \\
\text { Ketuntasan KKM }\end{array}$ \\
\hline Pengetahuan & $66,67 \%$ \\
Keterampilan & $74,07 \%$ \\
Sikap & $81,48 \%$ \\
\hline
\end{tabular}

Data di atas menyebutkan bahwa siswa yang mampu melampaui KKM untuk hasil belajar kognitif (pengetahuan) sebanyak 18 siswa atau sebesar $66,67 \%$. Sebanyak 20 siswa $(74,07 \%)$ telah mampu melampaui KKM untuk hasil belajar psikomotorik (keterampilan) dan 22 siswa 
$(81,48 \%)$ untuk siswa yang mampu melampaui KKM hasil belajar afektif. Hasil pada siklus ini belum mencapai indikator keberhasilan.

Data yang telah terkumpul dijadikan bahan pertimbangan pada tahap refleksi. Refleksi pada siklus 1 menunjukkan bahwa diperlukan adanya pedoman bagi siswa dalam menyelesaikan pekerjaan berupa lembar persiapan kerja dan tabel parameter pemotongan. Hasil refleksi ini dijadikan pedoman dalam pemberian tindakan di Siklus 2 .

\section{Siklus 2}

Siklus 2

dilaksanakan menggunakan model pembelajaran Practice Rehearsal Pairs dengan modifikasi yaitu siswa menyiapkan lembar persiapan kerja (Work Preparation Sheet) sebelum melakukan praktik dan menggunakan tabel parameter pemotongan sebagai pedoman mengerjakan job. Keaktifan siswa pada siklus ini terlihat meningkat dengan cukup signifikan. Peningkatan tersebut terlihat dari berkurangnya siswa yang sering bercanda dan lebih serius dalam mengikuti pembelajaran. Meskipun demikian, beberapa siswa masih sering bercanda dan mengganggu temannya, sehingga pembelajaran menjadi tidak kondusif. Keaktifan ini memengaruhi motivasi belajar siswa seperti yang ditunjukkan pada Tabel 4 berikut:

Tabel 4. Data Motivasi Belajar Siswa Siklus 2

\begin{tabular}{cc}
\hline Kategori & Persentase \\
\hline Sangat Baik & $44,4 \%$ \\
Baik & $48,2 \%$ \\
Cukup & $7,4 \%$ \\
Kurang & 0 \\
Sangat Kurang & 0 \\
\hline
\end{tabular}

Data di atas menyebutkan bahwa sebesar $92,6 \%$ siswa telah mencapai motivasi belajar berkategori baik. Angka tersebut diperoleh dari banyaknya siswa yang memiliki motivasi belajar berkategori sangat baik yaitu $40,7 \%$ ditambahkan 33,3\% siswa berkategori baik.

Penggunaan media Work Preparation Sheet dan Tabel Parameter Pemotongan mampu meningkatkan pemahaman siswa, karena siswa telah mempersiapkan diri sebelum melakukan pekerjaan. Hasil yang diperoleh pada siklus 2 ini cukup baik, namun masih ada siswa yang melakukan pemakanan terlalu kecil, sehingga waktu yang diperlukan lebih lama. Hasil belajar pada siklus 2 ditunjukkan pada Tabel 5 berikut: Tabel 5. Data Hasil Belajar Siswa Siklus 1

\begin{tabular}{cc}
\hline Hasil Belajar & $\begin{array}{c}\text { Persentase } \\
\text { Ketuntasan KKM }\end{array}$ \\
\hline Pengetahuan & $88,89 \%$ \\
Keterampilan & $88,89 \%$ \\
Sikap & $85,19 \%$ \\
\hline
\end{tabular}


Siswa yang mampu melampaui KKM untuk hasil belajar kognitif (pengetahuan) sebanyak 24 siswa atau sebesar 88,89\%. Sebanyak 24 siswa $(88,89 \%)$ telah mampu melampaui KKM untuk hasil belajar psikomotorik (keterampilan) dan 23 siswa $(85,19 \%)$ untuk siswa yang mampu melampaui KKM hasil belajar afektif. Hasil pada siklus ini telah melampaui indikator keberhasilan.

\section{Perbandingan Hasil Tindakan}

Data mengenai motivasi belajar dari semua siklus dapat dilihat pada Tabel 6 berikut.

Tabel 6. Perbandingan Data Motivasi Belajar Siswa

\begin{tabular}{ccc}
\hline Kategori & \multicolumn{2}{c}{ Persentase } \\
\cline { 2 - 3 } Motivasi & Siklus 1 & Siklus 2 \\
\hline Sangat Baik & $40,7 \%$ & $44,4 \%$ \\
Baik & $33.3 \%$ & $48,2 \%$ \\
Cukup & $26 \%$ & $7,4 \%$ \\
Kurang & 0 & 0 \\
Sangat Kurang & 0 & 0 \\
\hline
\end{tabular}

Motivasi belajar siswa mengalami perbaikan dari siklus 1 ke siklus 2. Pada siklus 1 persentase siswa yang memiliki motivasi belajar sangat baik sebesar 40,7\%. Angka tersebut meningkat menjadi sebesar $44,4 \%$ pada siklus 2. Peningkatan juga terjadi pada besarnya persentase siswa yang memiliki motivasi belajar dengan kategori baik yaitu dari $33.3 \%$ pada siklus 1 menjadi 48,2\% pada siklus 2 .
Berbeda dengan kedua kategori di atas, siswa dengan motivasi belajar berkategori cukup mengalami penurunan yaitu dari $26 \%$ menjadi $7,4 \%$. Penurunan ini tidak menunjukkan motivasi belajar menjadi buruk, sebaliknya penurunan ini menunjukkan bahwa motivasi belajar siswa menjadi lebih baik, karena siswa yang berkategori cukup meningkat menjadi berkategori baik. Data mengenai hasil belajar siswa terangkum dalam Tabel 7 berikut.

Tabel 7. Perbandingan Data Hasil Belajar Siswa

\begin{tabular}{cccc}
\hline \multirow{2}{*}{ Hasil Belajar } & \multicolumn{3}{c}{ Persentase } \\
\cline { 2 - 4 } & $\begin{array}{c}\text { Pra- } \\
\text { tindakan }\end{array}$ & Siklus 1 Siklus 2 \\
\hline Pengetahuan & $66,67 \%$ & $66,67 \%$ & $88,89 \%$ \\
Keterampilan & $70,37 \%$ & $74,07 \%$ & $88,89 \%$ \\
Sikap & $62,96 \%$ & $81,48 \%$ & $85,19 \%$ \\
\hline
\end{tabular}

Hasil belajar siswa mengalami perbaikan dari pratindakan hingga siklus 2, baik pada pengetahuan, keterampilan, maupun sikap. Hasil belajar kognitif siswa dari pratindakan ke siklus 1 tidak mengalami peningkatan maupun penurunan pada persentase siswa yang mampu mencapai KKM, yaitu sebesar $66,67 \%$. Persentase tersebut meningkat pada siklus 2 menjadi sebesar $88,89 \%$. Hal ini menunjukkan bahwa pengetahuan siswa meningkat pesat pada siklus 2. Peningkatan juga terjadi dalam hasil belajar 
psikomotorik atau keterampilan siswa yaitu dari $70,37 \%$ pada pratindakan menjadi $74,07 \%$ pada siklus 1 . Persentase tersebut meningkat lagi menjadi $88,89 \%$ pada siklus 2. Berbeda dengan hasil belajar kognitif yang mengalami peningkatan pesat pada siklus 2, hasil belajar afektif siswa justru mengalami peningkatan yang signifikan pada siklus 1 yaitu dari $62,96 \%$ menjadi $81,48 \%$. Pada siklus 2 persentasenya juga mengalami peningkatan, namun tidak terlalu signifikan yaitu sebesar $85,19 \%$. Secara umum hasil penelitian ini menunjukkan perubahan siswa ke arah perbaikan.

\section{PENUTUP}

\section{Simpulan}

Penerapan model pembelajaran Practice Rehearsal Pairs mampu meningkatkan motivasi belajar siswa kelas XI TMB pada pembelajaran Praktik Pemesinan di SMK Bhinneka Karya Surakarta. Siswa yang sudah memiliki motivasi belajar baik pada siklus 1 sebesar $74,07 \%$ meningkat menjadi $92,59 \%$ pada siklus 2.

Penerapan model pembelajaran Practice Rehearsal Pairs juga mampu meningkatkan hasil belajar siswa. Peningkatan tersebut ditandai dengan ketuntasan belajar siswa terhadap KKM dengan rincian sebagai berikut: a) Hasil belajar kognitif (pengetahuan) siswa meningkat dari $66,67 \%$ menjadi $88,89 \%$ siswa; b) Hasil belajar psikomotorik (keterampilan) siswa meningkat dari $74,07 \%$ menjadi $88,89 \%$ siswa; c) Hasil belajar afektif (sikap) siswa meningkat dari $81,48 \%$ menjadi $85,19 \%$ siswa.

\section{DAFTAR PUSTAKA}

Aunurrahman. (2014). Belajar dan Pembelajaran. Bandung: Alfabeta.

Purwanto, M. Ngalim. (2014). Psikologi Pendidikan. Bandung: PT Remaja Rosdakarya.

Silberman, Mel. (2009). Active Learning (101 Strategi Pembelajaran Aktif). Terj. Sarjuli, dkk. Yogyakarta: Pustaka Insan Madani.

Sukmadinata, Nana S. (2006). Metode Penelitian Pendidikan. Bandung: PT Remaja Rosdakarya.

Suprijono, Agus. (2015). Cooperative Learning. Yogyakarta: Pustaka Pelajar. 